\title{
Multidrug-resistant bacterial isolates from patients suspected of nosocomial infections at the University of Gondar Comprehensive Specialized Hospital, Northwest Ethiopia
}

Tigist Feleke ${ }^{1 *}$, Setegn Eshetie ${ }^{2}$, Mulat Dagnew ${ }^{2}$, Mengistu Endris $^{2}$, Wondwossen Abebe ${ }^{2}$, Moges Tiruneh ${ }^{2}$ and Feleke Moges $^{2}$

\begin{abstract}
Objectives: As the hospital environment favors the circulation of drug resistant bacteria, continuous surveillance of antibiotic resistant patterns is an important approach for a better patient management. This study is therefore, aimed to assess multidrug resistant bacterial isolates from patients suspected of nosocomial infections at the University of Gondar Comprehensive Specialized Hospital, Gondar, Ethiopia.

Results: Of the 260 patients, 173 (66.5\%) of them were culture positive. Among culture positive patients a total of 216 bacterial isolates were recovered, of which the most common species were S. aureus 77 (35.6\%), followed by E. coli 33 (15.3\%) and Klebsiella spp 29 (13.4\%). Of the S. aureus isolates, 67.5\% were cefoxitin (methicillin) resistant. Citrobacter spp (100\%), Klebsiella spp (79.3\%) and E. coli (75.3\%) were the leading MDR Gram-negative isolates. The overall MDR resistant rate was 152 (70.4\%).
\end{abstract}

Keywords: Nosocomial infections, Multidrug resistant, Gondar

\section{Introduction}

The impact of nosocomial infections (NIs) is an important public health concern due to the presence of increasing numbers of immunocompromised hospitalized patients, emergence of new strains of antibiotic resistant pathogens $[1,2]$. It is largely known that bacteria are the leading cause of NIs [3]. The most common types of NIs that could occur in a hospital set up are: surgical site infections, blood stream infections, urinary tract infections [4] respiratory infections, gastroenteritis, pneumonia and meningitis and other soft tissue infections [5].

Currently, antibiotics remain the leading therapy for treating bacterial infections. However, the irrational use

\footnotetext{
*Correspondence: tigistfeleke96@gmail.com

1 Department of Hospital Laboratory, University of Gondar

Comprehensive Specialized Hospital, P.O. Box: 196, Gondar, Ethiopia

Full list of author information is available at the end of the article
}

of antibiotics is no longer viewed as benign and certain strains of multidrug resistant bacteria have emerged by selection pressure; as a result, bacteria that have been once sensitive, re-emerged as resistant to different antibiotics and create limited therapeutic options, increased risks of treatment failure and poor patient management. As the incidence of antibiotic resistance rises, so do costs associate with its consequences. The worldwide emergence of multidrug resistant (MDR) among Gram-negative and Gram-positive bacteria has resulted in a great threat to efforts against bacterial pathogens [6]. It is clear that if there is no effective timely response, the challenge of antibiotic resistance is becoming alarming and will be a great challenge in the years to come. The aim of this study is therefore, to assess the rate of multidrug resistant bacterial isolates from patients suspected of nosocomial infections at the University of Gondar Comprehensive Specialized Hospital, Northwest Ethiopia. 


\section{Main text \\ Methods \\ Study area, study period and study population}

The study was conducted at the University of Gondar Comprehensive Specialized Hospital, Northwest of Ethiopia from February 1 to May 31, 2016. All inpatients in the hospital wards that were tentatively diagnosed by the responsible physicians who were suspected of nosocomial infection were study populations. Nosocomial infection is an infection occurring after $48 \mathrm{~h}$ of hospital admission or 3 days after discharge or infection occurs within 30 days after the operation [7].

\section{Sample size and sampling technique}

The sample size was determined by using a single population proportion formula using the prevalence rate of $16.4 \%$ [8] a total of 260 samples were included in the study. The study participants were enrolled consecutively using convenience sampling technique.

\section{Data collection and laboratory methods}

Data were collected using structured questionnaire consisting of the patient's demographic information. Clinical samples such as blood $(2 \mathrm{~mL}$ for children and $10 \mathrm{~mL}$ for adults), pus, wound discharge, morning midstream urine $(3 \mathrm{~mL})$, stool, eye discharge and body fluids were aseptically collected using sterile containers and transported promptly to the Microbiology laboratory with appropriate transport media. Identification of bacteria to species level was done using colony characteristics, gram reaction and different biochemical tests following standard procedure [9] and antimicrobial susceptibility testing of each isolates was checked using Muller-Hinton agar (Oxoid, England). Different antibiotic discs were used (Oxoid, England) following Kirby Bauer disc-diffusion method and interpreted following CLSI guidelines [10].

\section{Data analysis and interpretation}

Data were entered, and analyzed using SPSS version 23 software. Results were presented through graphs and tables. Statistical significance association was measured by using Chi square test and p value $<0.05$ was considered as statistically significant.

\section{Results}

A total of 260 hospitalized patients suspected of having nosocomial infections were assessed by culture. The $152 / 260(58.5 \%)$ of the study subjects were females. The age of the patients ranged from 1 to 85 years with the median age of $27.61 \pm 20.3$ years. The clinical samples
Table 1 Socio-demographic characteristics of inpatients suspected for nosocomial bacterial infections at the University of Gondar Comprehensive Specialized Hospital, 1st February-31st May 2016

\begin{tabular}{|c|c|c|c|}
\hline \multirow[t]{2}{*}{ Characteristic } & \multicolumn{3}{|c|}{ Culture positivity rate } \\
\hline & Yes $n=173(\%)$ & No $n=87(\%)$ & Total $n=260(\%)$ \\
\hline \multicolumn{4}{|l|}{ Age (years) } \\
\hline$\leq 15$ & $44(25.4)$ & $36(41.4)$ & $80(30.8)$ \\
\hline $16-30$ & $63(36.4)$ & $20(23)$ & $83(31.9)$ \\
\hline$\geq 31$ & $66(38.2)$ & $31(35.6)$ & $97(37.3)$ \\
\hline \multicolumn{4}{|l|}{ Sex } \\
\hline Male & $67(38.8)$ & $41(47.1)$ & $108(41.6)$ \\
\hline Female & $106(61.3)$ & $46(52.9)$ & $152(58.5)$ \\
\hline \multicolumn{4}{|l|}{ Occupation } \\
\hline Civil servant & $29(16.8)$ & $18(20.7)$ & $47(18.1)$ \\
\hline Farmer & $41(23.7)$ & 19 (21.9) & $60(23.0)$ \\
\hline Student & $30(17.3)$ & $11(12.6)$ & $41(15.8)$ \\
\hline Private & $46(26.6)$ & $14(16.1)$ & $60(23.1)$ \\
\hline Others & $27(15.6)$ & $25(28.7)$ & $52(20)$ \\
\hline \multicolumn{4}{|c|}{ Educational status } \\
\hline Illiterate & $69(39.9)$ & $35(40.2)$ & $104(40)$ \\
\hline $\begin{array}{l}\text { 1st cycle com- } \\
\text { plete }\end{array}$ & $39(22.5)$ & $25(28.8)$ & $64(24.6)$ \\
\hline $\begin{array}{l}\text { 2nd cycle } \\
\text { complete }\end{array}$ & $36(20.8)$ & $10(11.5)$ & $46(17.7)$ \\
\hline $\begin{array}{l}\text { Diploma and } \\
\text { above }\end{array}$ & $29(16.8)$ & $17(19.5)$ & $46(17.7)$ \\
\hline \multicolumn{4}{|l|}{ Marital status } \\
\hline Single & $77(44.5)$ & $47(54)$ & $124(47.7)$ \\
\hline Married & $77(44.5)$ & $34(39.1)$ & $111(42.7)$ \\
\hline Divorced & $19(11.0)$ & $6(6.9)$ & $25(9.6)$ \\
\hline \multicolumn{4}{|l|}{ Specimen } \\
\hline Wound/pus & $105(60.7)$ & $12(13.8)$ & $117(45)$ \\
\hline Urine & $33(19.1)$ & $27(31.1)$ & $60(23.1)$ \\
\hline Blood & $25(14.5)$ & 31 (35.6) & $56(21.5)$ \\
\hline Stool & $5(2.9)$ & $10(11.5)$ & $15(5.8)$ \\
\hline Eye discharge & $4(2.3)$ & $1(1.1)$ & $5(1.9)$ \\
\hline $\begin{array}{l}\text { Other body } \\
\text { fluids }^{\text {a }}\end{array}$ & $1(0.6)$ & $6(6.9)$ & $7(2.7)$ \\
\hline \multicolumn{4}{|l|}{ Ward } \\
\hline Surgical & $68(39.3)$ & $14(16.1)$ & $82(31.5)$ \\
\hline Pediatrics & $41(23.7)$ & $36(41.4)$ & 77 (29.6) \\
\hline Medical & $30(17.3)$ & $26(29.9)$ & $56(21.5)$ \\
\hline Gynecology & $28(16.2)$ & $6(6.9)$ & $34(13.1)$ \\
\hline Mixed ward & $6(3.5)$ & $5(5.7)$ & $11(4.2)$ \\
\hline Total & $173(66.5)$ & $87(33.5)$ & $260(100)$ \\
\hline
\end{tabular}

a Other body fluids = brain abscesses, joint fluids, pleural fluids

collected were mainly wound discharge, pus, urine, blood, stool, eye discharge and body fluids (Table 1).

Of the 260 patients' specimens cultured, 173/260 $(66.5 \%)$ of them were culture positive and $87 / 260$ (33.5\%) were culture negative. The highest prevalence of infection 


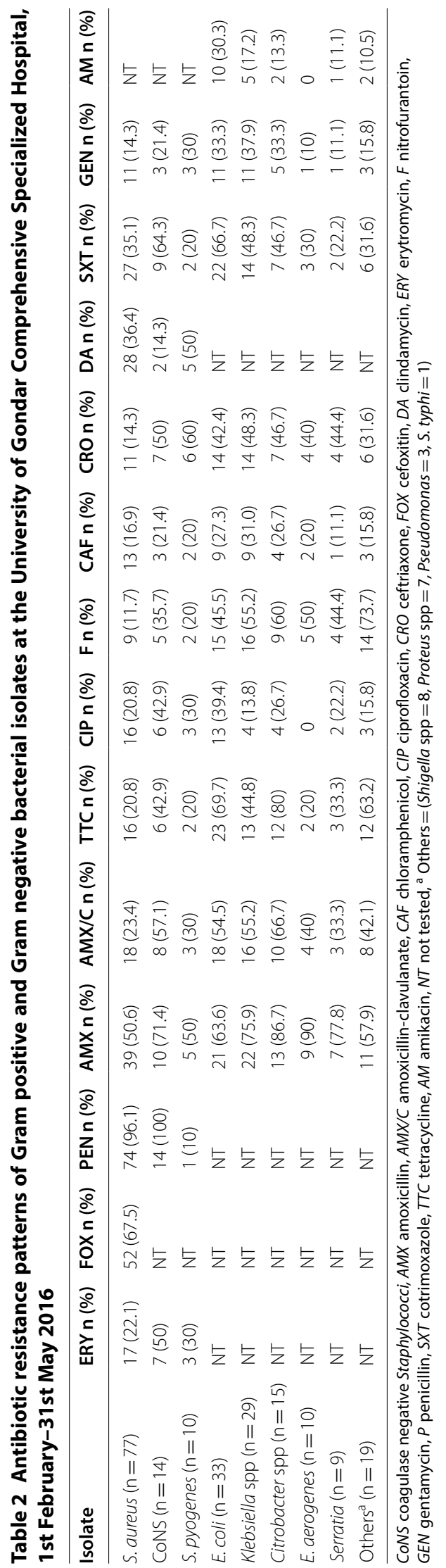


was found from Surgical ward 68/173 (39.3\%) followed by Pediatrics ward 41/173 (23.7\%), Medical ward 30/173 (17.3\%) and Gynecology ward 28/173 (16.2\%). Of the 173 clinical samples positive for culture, 216 bacterial isolates were identified (131 sample with single infection, 41 with double infection and 1 with triple infection). The most common clinical sample assessed was wound/ pus $117 / 260(45 \%)$, followed by urine $60 / 260(23.1 \%)$ and blood 56/260 (21.5\%) (Table 1). Out of 173 (66.5\%) samples, a total of 216 bacterial isolates were recovered, of which 101/216 (46.8\%) were Gram-positives and 115/216 (53.2\%) were Gram-negatives. The most common isolates were $S$. aureus $77 / 216$ (35.6\%), E. coli 33/216 (15.3\%) and Klebsiella spp 29/216 (13.4\%).

Antibiotic resistance patterns of Gram positive bacteria showed that, $S$. aureus was resistant to penicillin 74/77 (96.1\%), cefoxitin 52/77 (67.5\%) (surrogate marker for methicillin-resistant $S$. aureus (MRSA)), amoxicillin 39/77 (50.6\%), clindamycin 28/77 (36.4\%) and cotrimoxazole $27 / 77$ (35.1\%). The resistance patterns of coagulase negative Staphylococci (CoNS) to penicillin were $14 / 14(100 \%)$. Higher resistance rate to S. pyogenes was observed in ceftriaxone $6 / 10$ (60\%), amoxicillin and clindamycin $5 / 10$ (50\% each) and lowest resistance rate in penicillin 1/10 (10\%) (Table 2).

Among Gram-negatives, E. coli was resistant to tetracycline 23/33 (69.7\%), cotrimoxazole 22/33 (66.7\%), amoxicillin $21 / 33(63.6 \%)$, amoxicillin-clavulanate $18 / 33$ (54.5\%) and least resistant to chloramphenicol 9/33 (27.3\%). Klebsiella spp were resistant to amoxicillin 22/29 (75.9\%), amoxicillin/clavulanate and nitrofurantoin (each) 16/29 (55.2\%) and cotrimoxazole and ceftriaxone (each), 14/29 (48.3\%). Citrobacter spp were resistant to amoxicillin 13/15 (86.7\%), tetracycline 12/15 (80\%) and amoxicillin/clavulanate 10/15 (66.7\%) E. aerogenes was 9/10 (90\%) resistant to amoxicillin and 5/10 (50\%) to nitrofurantoin. However, $90 \%$ of the isolates of $E$. aerogenes were susceptible to gentamicin and all isolates of $E$. aerogenes were susceptible to amikacin and ciprofloxacin (Table 2). Higher number of multi-drug resistant isolates were recorded in the present study in Citrobacter spp 15/15 (100\%), followed by CoNS12/14 (85.7\%), Klebsiella spp 23/29 (79.3\%), E. coli $25 / 33$ (75.8\%), and S. aureus 47/77 (61\%). The overall MDR resistant in this study was 152/216 (70.4\%) (Table 3).

\section{Discussion}

The present study showed that $66.5 \%$ of the inpatients had bacterial infections. This result is in line with a study reported from Dessie, Northeast Ethiopia (70.5\%) [11]. However, our result is lower than studies from Jimma Hospital (87.3\%) and Addis Ababa Hospitals (84.1\%) $[12,13]$. These variations may be due to differences in clinical samples, methodological variations, and study settings. Of the 173 culture positive patients, 131 (75.7\%) had single infections, 41 (23.7\%) double infections and $1(0.6 \%)$ triple bacterial infections. These findings were consistent with a report in Brazil, 23.3\% with polymirobial infections [14]. However, slightly lower results of polymicrobial growth were reported by Sikka et al. [15], $14.3 \%$ and Singh et al. [16], 11.3\%. The difference in polymicrobial infection might be due to the fact that, most of the patients were with surgical site infections, the patient-related factors, poor equipment quality, financial resources as well as the competence of the surgical team [17].

In the present study, high rate of Gram negative (53.2\%) bacteria were the causative agents of nosocomial infections than Gram-positives (46.8\%). Similarly, Gram-negative bacteria as the leading cause of nosocomial infection were reported from Addis Ababa Hospitals 76 (73\%) [13] and Jimma Hospital 53\% [12]. Furthermore, Gramnegative organisms constituted more than three quarters (78.3\%) of all causative organisms in hospital associated infections in Ibadan, Nigeria than Gram positives [18]. The higher proportion of the Gram-negative bacteria might be ascribed that most study participants had under gone abdominal surgery and Gram negatives are predominantly reported tobe involved in intra-abdominal procedures [19].

S. aureus 77 (35.6\%) and E. coli 33 (15.3\%) were the most common isolates reported in this study. Similar results reported from Jimma, revealed that the predominant organisms isolated from wound infection were $S$. aureus $47(32.4 \%)$ and E. coli 29 (20\%) [12]. The most common clinical samples that revealed high frequency of isolation were wound/pus 136 (63\%), followed by urine 40 (18.5\%) and blood 29 (13.4\%). These findings are in line with other studies done in Gabon and Ethiopia [17, 20]. On the contrary, the present study is different from other studies elsewhere [21-23]. The variations in this report may be due to host, microbial and environmental factors [24].

Among Gram-positive bacteria, S. aureus and CoNS were the most common isolates that causes nosocomial infections. This is in line with reports from India revealed that S. aureus and CoNS were commonly isolated Gram positive bacteria [25]. Of the total isolates of nosocomial infections S. aureus was the most common isolate, $35.6 \%$. This was consistent from studies in Jimma, Nigeria and India $[12,26,27]$. S. aureus is a common pathogen due to its ubiquitous nature both as a normal skin flora and a pathogen in human host $[28,29]$. Furthermore, MRSA isolation rate in this study was $67.5 \%$. This was higher than 55\% MRSA reported by Abera et al. [30] in Ethiopia. The high rate of prevalence in the present study may 
Table 3 Multidrug resistance patterns of bacterial isolates from inpatients suspected for nosocomial bacterial infections at the University of Gondar Comprehensive Specialized Hospital, 1st February-31st May 2016

\begin{tabular}{|c|c|c|c|c|c|c|c|c|c|c|}
\hline \multirow[t]{2}{*}{ Isolates } & \multicolumn{10}{|c|}{ Degree of resistance } \\
\hline & R0 n (\%) & R1 n (\%) & R2 n (\%) & R3 n (\%) & R4 n (\%) & R5 n (\%) & R6 n (\%) & R7 n (\%) & $R \geq 8$ n (\%) & $M R^{a} n=(\%)$ \\
\hline S. aureus $(n=77)$ & - & $11(14.3)$ & $19(24.7)$ & $6(7.8)$ & $12(15.6)$ & $6(7.8)$ & $6(7.8)$ & $4(5.2)$ & $13(16.9)$ & $47(61.0)$ \\
\hline E. coli $(\mathrm{n}=33)$ & - & $5(15.1)$ & $3(9.1)$ & $4(12.1)$ & $2(6.1)$ & $4(12.1)$ & $1(3.0)$ & $1(3.0)$ & $13(39.4)$ & $25(75.8)$ \\
\hline Klebsiella spp $(\mathrm{n}=29)$ & - & $3(10.3)$ & $3(10.3)$ & $2(6.9)$ & $5(17.2)$ & $3(10.3)$ & $3(10.3)$ & $2(6.9)$ & $8(27.6)$ & $23(79.3)$ \\
\hline Citrobacter spp $(n=15)$ & - & - & - & $4(26.7)$ & $3(20)$ & $1(6.7)$ & $1(6.7)$ & $1(6.7)$ & $5(3.3)$ & $15(100)$ \\
\hline CoNS $(n=14)$ & - & $1(7.1)$ & $1(7.1)$ & $2(14.3)$ & $1(7.1)$ & - & $4(28.6)$ & - & $5(36.7)$ & $12(85.7)$ \\
\hline E. aerogenes $(n=10)$ & & $1(10)$ & $2(20)$ & $3(30)$ & - & - & $3(30)$ & - & $1(10)$ & $7(70.0)$ \\
\hline S. pyogenes $(n=10)$ & $2(20)$ & $2(20)$ & $1(10)$ & $2(20)$ & - & - & - & - & $3(30)$ & $5(50.0)$ \\
\hline Serratia $(n=9)$ & - & $1(11.1)$ & $3(33.3)$ & $1(11.1)$ & $1(11.1)$ & $1(11.1)$ & - & $1(11.1)$ & $1(11.1)$ & $5(55.6)$ \\
\hline Others $^{b}(n=19)$ & - & $3(1.6)$ & $3(1.6)$ & $1(5.3)$ & $6(31.6)$ & & $1(5.3)$ & $1(5.3)$ & $4(21.1)$ & $13(68.4)$ \\
\hline Total $(n=216)$ & $2(0.9)$ & $27(12.5)$ & $35(16.2)$ & $25(11.6)$ & 30 13.9) & $15(6.9)$ & $19(8.8)$ & $10(4.6)$ & $53(24.5)$ & $152(70.4)$ \\
\hline
\end{tabular}

CoNS coagulase negative Staphylococci

a $\mathrm{MDR}=$ isolates resistant to 3 or more antibiotics classes. $\mathrm{R} 0=$ all are sensitive, $\mathrm{R} 1=$ resistant to one antibiotic classes, $\mathrm{R} 2=$ resistant to two antibiotic classes etc.,

$\mathrm{R} \geq 8$ resistant to greater or equal to 8 antibiotics

b Others (Shigella $\mathrm{spp}=8$, Proteus $\mathrm{spp}=7$, Pseudomonas $=3$, S. typhi $=1$ )

be due to the fact that like many other African countries MRSA prevalence is increasing from time to time [31].

Among Gram-negative isolates, E. coli (15.3\%), Klebsiella spp (13.4\%), Citrobacter spp (7.0\%) were commonly isolated pathogens. This is consistent with culture results of different specimens in Iran which revealed that E. coli and Klebsiella pneumoniae were the most common isolates [32].

The antibiotic resistance patterns of the isolates were also assessed: hence high resistant $S$. aureus isolates were identified against penicillin (96.1\%), amoxicillin (50.6\%), clindamycin (36.4\%) and cotrimoxazole (35.1\%). Besides, of the $S$. aureus isolates, $67.5 \%$ were resistant to cefoxitin, a surrogate marker for MRSA [33]. Similarly, higher rate of MRSA (76.7\%) was reported by Godebo et al. [34]. However, lower rate of MRSA reported by Nigussie et al. [35] and Latif et al. [36] as $38.5 \%$ and $31.25 \%$, respectively. These variations may be due to the type of assessment used for diagnosis of MRSA and status of the hospital.

In this study Citrobacter spp (100\%), Klebsiella spp (79.3\%) and E. coli (75.3\%) were the leading MDR Gramnegative isolates. The $100 \%$ MDR Citrobacter seen in this study is consistent with $100 \%$ MDR rate reported both in Jimma Hospital, Ethiopia and Pakistan [34, 37]. Overall multi-drug resistance rate in this study was 152 (70.4\%). This result is consistent with results reported in South Africa [38] and Jimma Hospital (68.1\%) [34] but relatively higher than reports from Dessie, 65.2\% [10] and lower than from Bahir Dar Hospital 93.1\% [39].

Based on the present study, 67.5\% MRSA, 100\% penicillin resistant CoNS, high rate of MDR in Citrobacter spp (100\%), Klebsiella spp (79.3\%) and E. coli (75.3\%) were documented. The overall MDR rate was $70.4 \%$. Therefore, finding high MDR isolates in this hospital warrants a need to establish a better diagnostics and functional antimicrobial stewardship.

\section{Limitation of the study}

Addressing MRSA and MDR Gram negative bacterial pathogens from culture of 260 clinical samples may be timely. However, complete characterization of resistance mechanisms and clonal relatedness was not made and considered as a limitation of this study.

\section{Abbreviations \\ MDR: multidrug resistance (acquired resistance to three or more different classes of antimicrobial agents); CoNS: coagulase negative Staphylococci; MRSA: methicillin resistant S. aureus; NIs: nosocomial infections.}

\section{Authors' contributions}

TF was conceived the study, designed data collection, conducted data analysis and interpretation. FM, MT, SE, ME, MD and WA interpreted the results and reviewed the initial and final drafts of the manuscript. All authors read and approved the final manuscript.

\section{Author details}

1 Department of Hospital Laboratory, University of Gondar Comprehensive Specialized Hospital, P.O. Box: 196, Gondar, Ethiopia. ${ }^{2}$ Department of Medical Microbiology, School of Biomedical and Laboratory Sciences, College of Medicine and Health Sciences, University of Gondar, Gondar, Ethiopia.

\section{Acknowledgements}

We would like to thank study participants.

\section{Competing interests}

The authors declare that they have no competing interests.

Availability of data and materials

All data generated or analyzed during this study were included in this article. 


\section{Consent for publication \\ Not applicable.}

\section{Ethical approval and consent to participate}

Ethical approval was obtained from the School of Biomedical and Laboratory Sciences of the University of Gondar ethical review committee with reference number SBMLS/66/08. Informed written consent was obtained from each study participants. Children less than 18 years who are not able to give consent were also asked an assent and written consent were taken from their parents or guardians.

\section{Funding}

The study was supported by the mega project of the University of Gondar in Reference number of VP/RCS/05/192/2015.

\section{Publisher's Note}

Springer Nature remains neutral with regard to jurisdictional claims in published maps and institutional affiliations.

Received: 3 July 2018 Accepted: 14 August 2018

Published online: 20 August 2018

\section{References}

1. Sah MK, Mishra SK, Ohora H, Kirikae T, Sherchan JB, Rijal BP, Pokhrel BM Nosocomial bacterial infection and antimicrobial resistant pattern in a tertiary care hospital in Nepal. J Inst Med. 2014;36:37-48.

2. Allegranzi B, Bagheri Nejad S, Combescure C, Graafmans W, Attar H, Donaldson L, et al. Burden of endemic health-care-associated infection in developing countries: systematic review and meta-analysis. Lancet. 2011;377(9761):228-41

3. Nnis S. National Nosocomial Infections Surveillance (NNIS) System Report, data summary from January 1990-May 1999, issued June 1999. A report from the NNIS System. Am J Infect Control. 1999;27(6):520.

4. Endalafer N, Gebre-Selassie S, Kotiso B. Nosocomial bacterial infections in a tertiary hospital in Ethiopia. J Infect Prev. 2011;12:38-43.

5. Raka L, Zoutman D, Mulliqi G, Krasniqi S, Dedushaj I, Raka N, et al. Prevalence of nosocomial infections in high-risk units in the university clinica center of Kosova. Infect Control. 2006;27(04):421-3.

6. Thomas Hooton M, Stuart B, Levy MD. Confronting the antibiotic resistance crisis: making appropriate therapeutic decisions in community medical practice. Infect Med. 2004;21(3):114-22.

7. Inweregbu K, Dave J, Pittard A. Nosocomial infections. Contin Educ Anaesth Crit Care Pain. 2005;5:14-7.

8. Habte-Gabr E, Gedebou M, Kronvall G. Hospital-acquired infections among surgical patients in Tikur Anbessa Hospital, Addis Ababa, Ethiopia. Am J Infect Control. 1988;16(1):7-13.

9. Cheesbrough M. District laboratory practice in tropical countries. New York: Cambridge University Press; 2006.

10. Clinical and Laboratory Standards Institute (CLSI). Performance standards for antimicrobial susceptibility testing; twenty-second informational supplement. 27th ed. CLSI Suppliment M100 Wayne, PA: Clinical and Laboratory Standards Institute; 2017

11. Azene MK, Beyene BA. Bacteriology and antibiogram of pathogens from wound infections at Dessie Laboratory, North East Ethiopia. Tanzania J Health Res. 2011:13:1-10.

12. Mama M, Abdissa A, Sewunet T. Antimicrobial susceptibility pattern of bacterial isolates from wound infection and their sensitivity to alternative topical agents at Jimma University Specialized Hospital, South-West Ethiopia. Ann Clin Microbiol Antimicrob. 2014;13(1):1.

13. Dessie W, Mulugeta G, Fentaw S, Mihret A, Hassen M, Abebe E. Pattern of bacterial pathogens and their susceptibility isolated from surgical site infections at selected referral hospitals, Addis Ababa, Ethiopia. Int J Microbiol. 2016. https://doi.org/10.1155/2016/2418902

14. Moraes BAd, Cravo CAN, Loureiro MM, Solari CA, Asensi MD. Epidemiological analysis of bacterial strains involved in hospital infection in a University Hospital from Brazil. Revista do Instituto de Medicina Tropical de São Paulo. 2000;42(4):201-7.
15. Sikka R, Mann J, Deep VM, Chaudhary U, Deep A. Prevalence and antibiotic sensitivity pattern of bacteria isolated from nosocomial infections in a surgical ward. Indian J Clin Pract. 2012;22:519-25.

16. Singh A, Sen M, Anupurba S, Bhattacharya P. Antibiotic sensitivity pattern of the bacteria isolated from nosocomial infections in ICU. J Commun Dis. 2002;34(4):257-63

17. Scherbaum M, Kösters K, Mürbeth RE, Ngoa UA, Kremsner PG, Lell B, et al. Incidence, pathogens and resistance patterns of nosocomial infections at a rural hospital in Gabon. BMC Infect Dis. 2014;14(1):1.

18. Ige O, Adesanmi A, Asuzu M. Hospital-acquired infections in a Nigerian tertiary health facility: an audit of surveillance reports. J Nigeria Med Assoc. 2011:52(4):239.

19. Bibi S, Channa GA, Siddiqui TR, Ahmed W. Pattern of bacterial pathogens in postoperative wounds and their sensitivity patterns. J Surg Pak (Int). 2012;17(4):164-7

20. Yallew WW, Kumie A, Yehuala FM. Point prevalence of hospital-acquired infections in two teaching hospitals of Amhara region in Ethiopia. Drug Healthc Patient Safety. 2016:8:71-6.

21. Wenzel RP. Importance of infection control. In: Wenzel R, Brewer T, Butzler J-P, editors. A guide to infection control in the hospital. 3rd ed. Boston: The International Society for Infectious Diseases; 2004. p. 1-4.

22. Greco D, Magombe I. Hospital acquired infections in a large north Ugandan hospital. J Prev Med Hyg. 2011;52:55-8.

23. Lee C-Y, Chen P-Y, Huang F-L, Lin C-F. Microbiologic spectrum and susceptibility pattern of clinical isolates from the pediatric intensive care unit in a single medical center-6 years' experience. J Microbiol Immunol Infect. 2009:42(2):160-5.

24. Dusé A. Infection control in developing countries with particular emphasis on South Africa. South Afr J Epidemiol Infect. 2005;20(2):37-41

25. Gupta R, Malik A, Rizvi M, Ahmed M, Hashmi A. Multidrug resistant Gram positive pathogens with special reference to MRSA and biofilm production in ICU patients: recurrent challenge for clinicians. Int J Curr Microbiol App Sci. 2015;Special Issue-1: 207-12.

26. Oli AN, Okoli KC, Ujam NT, Adje DU, Ezeobi I. Health professionals' knowledge about relative prevalence of hospital-acquired infections in Delta State of Nigeria. Pan Afr Med J. 2016;24:148. https://doi. org/10.11604/pamj.2016.24.148.9270.

27. Taneja N, Emmanuel R, Chari P, Sharma M. A prospective study of hospital-acquired infections in burn patients at a tertiary care referral centre in North India. Burns. 2004;30(7):665-9.

28. Nwoire A, Madubuko E, Eze U, Oti-Wilberforce R, Azi S, Ibiam G, et al. Incidence of Staphylococcus aureus in clinical specimens in Federal Teaching Hospital, Abakaliki, Ebonyi State. Merit Res J Med Med Sci. 2013;1(3):043-6.

29. Akindele A, Adewuyi I, Adefioye O, Adedokun S, Olaolu A. Antibiogram and beta-lactamase production of Staphylococcus aureus isolates from different human clinical specimens in a tertiary health institution in lle-ife, Nigeria. Am Eurasian J Sci Res. 2010;5(4):230-3.

30. Abera B, Alem A, Bezabih B. Methicillin-resistant strains of Staphylococcus aureus and coagulase-negative staphylococus from clinical isolates at Felege Hiwot Refferal Hospital, North West Ethiopia. Ethiop Med J. 2008:46:149-54.

31. Falagas ME, Karageorgopoulos DE, Leptidis J, Korbila IP. MRSA in Africa: filling the global map of antimicrobial resistance. PLOS ONE. 2013;8(7):e68024. https://doi.org/10.1371/journal.pone.0068024.

32. Moini AS, Soltani B, Ardakani AT, Moravveji A, Erami M, Rezaei MH, Namazi M. Multidrug-Resistant Escherichia coli and Klebsiella pneumoniae isolated from patients in Kashan, Iran. Jundishapur J Microbiol. 2015:8(10):e27517

33. Fernandes CJ, Fernandes LA, Collignon P. Resistance AGoA. Cefoxitin resistance as a surrogate marker for the detection of methicillin-resistant Staphylococcus aureus. J Antimicrob Chemother. 2005;55(4):506-10.

34. Godebo G, Kibru G, Tassew H. Multidrug-resistant bacterial isolates in infected wounds at Jimma University Specialized Hospital, Ethiopia. Ann Clin Microbiol Antimicrob. 2013;12(1):1.

35. Negussie A, Mulugeta G, Bedru A, Ali I, Shimeles D, Lema T, et al. Bacteriological profile and antimicrobial susceptibility pattern of blood culture isolates among septicemia suspected children in selected hospitals Addis Ababa, Ethiopia. Int J Biol Med Res. 2015:6(1):4709. 
36. Latif S, Anwar MS, Ahmad I. Bacterial pathogens responsible for blood stream infection (BSI) and pattern of drug resistance in a tertiary care hospital of Lahore. Biomedica. 2009;25(2):101-5.

37. Shaikh D, Zaidy S, Shaikh K, Shaikh M, Naqvi BS, Shaikh M. Post surgical wound infections: a study on threats of emerging resistance. Pak J Pharmacol. 2003;20(1):31-41.
38. Dramowski A, Cotton MF, Rabie H, Whitelaw A. Trends in paediatric bloodstream infections at a South African referral hospital. BMC Pediatrics. 2015;15(1):1.

39. Biadglegne F, Abera B, Alem A, Anagaw B. Bacterial isolates from wound infection and their antimicrobial susceptibility pattern in Felege Hiwot referral Hospital North West Ethiopia. Ethiop J Health Sci. 2009;19:173-7.
Ready to submit your research? Choose BMC and benefit from:

- fast, convenient online submission

- thorough peer review by experienced researchers in your field

- rapid publication on acceptance

- support for research data, including large and complex data types

- gold Open Access which fosters wider collaboration and increased citations

- maximum visibility for your research: over $100 \mathrm{M}$ website views per year

At BMC, research is always in progress.

Learn more biomedcentral.com/submissions 